3. In reference to the size of the Aptychus, it seems natural that it should not exactly fit the aperture of the shell, for if it did the animal would have to be continually opening the lid to obtain fresh water; while if there were abundant space between the operculum and the shell-wall, the animal could breathe continuously in a contracted condition, and the presence of "stries creuses" in the test of many Ammonites (produced by the tightening of the muscular walls, so that they were thrown up into little ridges which left their imprint on the inner shell) seems to necessitate the power of doing so. While, again, if the Aptychus were poisonous, as I have suggested, and not merely a passive protection, there would be no necessity for the orifice to be closely shut. At any rate, then, there seems abundant evidence that the Aptychus could perform useful functions as an operculum without having to fit the aperture exactly.

In conclusion, I have shown that the theories against the Aptychus being an operculum can be met with equally plausible ones in favour of that view; and the fact that the Aptychus is known in one specimen to have officiated in that capacity, ought to throw suspicion on the other theories.

\title{
NOTICES OF IMEMTOIRS.
}

Abstracts of Papers read before the British Association at Oxford, August 9-14, 1894.

I.-The Probable Range of the Coal-measures under the Newer Rocks of Oxfordshire and the Adjolning Counties. By Professor Boyd-Dawkins, F.R.S.

TाHE principle laid down by Godwin-Austen and Prestwich that the master or tectonic folds in the pre-Carboniferous and Carboniferous rocks are lines of weakness along which the newer rocks have been folded in later times, has been recently applied by Bertrand to the district of northern France. In the present communication the author proposes to see how far it can be used in the search after the buried Coal-fields of the counties of Oxford, Buckingham, Berks, and Wilts.

From the relation existing between the tectonic anticlines and synclines in the districts of South Wales, Gloucester, and the West of England, where they can be studied at the surface in the Palæozoic rocks, most important conclusions may be drawn as to the Coal-fields buried under the newer rocks in southern England. They are as follows:-

1. The Mid-Devon syncline, traceable eastwards until it cuts the sea-line near Bognor.

2. The North Devon anticline, which runs eastwards through the Vale of Wardour, past Salisbury, and along the anticline of the Weald from Petersfield to Dungeness.

3. The Mid-Somerset syncline, which sweeps eastward through the Vale of Bridgewater and Glastonbury, through the Chalk downs between Heytesbury and Hindon, to Haslemere. From this point 
it is continned to the east through Tunbridge Wells and Tenterden to the sea to the south of Hythe.

These three folds have no bearing on the range of the Coal-fields in the drainage area of the Thames. The fourth, or PembrokeMendip anticline, and the fifth, or South Welsh syncline, are the two great tectonic folds which remain for consideration.

The Pembroke-Mendip anticlinal range, highly faulted and folded, is traceable westwards into South Ireland, and eastwards through Pembroke and the peninsula of Gower, to the south of Cardiff, through Weston-super-Mare and the Mendip Hills. Throughout this area it forms the southern margin of the Coal-fields. Near Frome it plunges beneath the Oolites. It is, however, clearly marked by the Upper Greensand anticline of the Vale of Pewsey, and by the Upper Greensand inliers of Ham and Kingsclere. Thence it passes along the line to the high downs past Basingstoke and Farnham to Peasemarsh, south of Guildford, where it is seen in an inlier of Weald clay. It is carried still further to the east by similiar inliers south of Westerham, and at Wateringbury and Maidstone. From Maidstone it sweeps to the south-east, through Otham and Ashford, arriving at the coast close to Hythe. In the eastern portion of its course it has, in my opinion, been the chief factor causing the south-eastern trend of the North Downs in the district of Maidstone. It forms also the southern boundary of the south-eastern Coal-field discovered in the boring at Dover, and of the Coal-fields of northern France and Belgium.

The South Welsh syncline, only two miles wide at St. Bride's Bay, in the anthracite district of Pembroke, widens out in to the Coal-field of South Wales, twenty miles in width. As it approaches the upper estuary of the Severn it is represented by the outlying Coal-field of the Forest of Dean, and the three partially or wholly cQvered fields to the north of the Mendip Hills, distributed through an area measuring forty-five miles from north to south. The wedgelike syncline with its more or less connected Coal-fields continues to widen eastwards, its northern boundary being probably represented by a line drawn from the northern rim of the South Welsh Coalfield to the north of the Forest of Dean, and continued due east beneath the Secondary and Tertiary rocks to some point between Walton-on-the-Naze and the mouth of the Blackwater. It passes through Gloucester, Rissington in the valley of the Windrush, Blenheim, Kirtlington, Quainton, Luton, Bishop's Stortford, Dunmow, Braintree, and Colchester. The width of this great tectonic syncline between Colchester and Dover is about fifty miles, and it occupies nearly the whole of the London Tertiary basin, which, it must be noted, is of the same wedge shape, widening to the east.

The boring recently deseribed by Mr. Whitaker at Culford, near Bury St. Edmunds, in which a slate rock, probably of Silurian or pre-Silurian age, was struck at a depth of 637 feet 6 inches from the surface, shows that in all probability that area is an anticlinal area. About forty-two miles to the south, in the deep boring at Harwich, the Yoredale shales come in. Both these points are, be it 
remarked, to the north of the line in question. Both indicate a Palæozoic area in Suffolk and northern Essex older than the Coalmeasures, and similar to that on the same meridian in South Wales and Gloucestershire which lies to the north of the western Coalfields. We have, therefore, not merely a well-defined PembrokeMendip anticlinal forming the southern boundary of the Coal-fields both in the west and in the east, as proved by the south-eastern Coal-field at Dover, but also evidence of the continuation of the South Welsh pre-Carboniferous barrier of Hull, which forms the northern boundary of the visible Coal-fields due eastwards into Suffolk. It may, therefore, be reasonably inferred that similar Coal-fields, isolated from each other by tracts of older rocks, are to be fonnd in the South Welsh syncline, where it lies buried beneath the Secondary and Tertiary strata. In other words, we may conclude that there are Coal-fields in North Wilts, in the counties of Berks, Oxford, and Buckingham, and the Tertiary basin of the Thames within the limits laid down above, and in a direction indicated in 1871 by the Coal Commissioners.

One such Coal-field, indeed, has already been discovered in a deep boring at Burford, near Whitney, in the valley of the Windrush. The discovery, however, has unfortunately not been followed up, and we do not know whether it is of wide east and west range, similar to that of South Wales, or of Bethune and Namur, or whether it is small and unimportant, like some of the smaller Coal-basins north of the Mendip Hills. It offers a sure basis for other deep borings, which might have the same industrial effect on Oxfordshire as those which have extended the range of the buried Coal-measures in northern France, ninety miles to the west of Charleroi, and converted a purely agricultural into a great manufacturing district. There is no practical difficulty arising from the depth at which the Coal-measures may be expected to occur in this region. At Burford they were struck at 1184 feet from the surface, and at Dover at 1113 feet below high-water mark.

The borings in the area of the London Tertiaries prove that the Palæozoic rocks are not buried to a greater depth than about 1200 feet below sea-level, and in Hertfordshire to as little as 796 feet. The most important collieries in England are carried on at depths ranging frem 1500 to more than 3000 feet. The new light thrown upon the question of the buried Coal-fields by recent discoveries places it in a very different position from that which it occupied in 1871, when Godwin-Austen, Prestwich, and Hull gave their evidence before the Royal Commission.

The boring at Dover, revealing the existence of a valuable Coalfield, now offers a fixed point for further discovery in south-eastern England. That at Burford offers a similar basis for the proving of the Oxfordshire Coal-field. The many other wells and borings made in the area of London, and as far north as Bury St. Edmunds, also afford important information as to the northern boundary of the productive South Welsh syncline. 'The development of our mineral wealth is of such vast importance that it would be quite worth the 
while of the Government to undertake a series of experimental borings, which would indicate the exact position of the buried Coalfields. In the present state of the mining laws it is a task not likely to be undertaken by the private adventurer. It might, however, be carried out by the County Councils, or by a combination of landowners, either with or without a compulsory rate, as the property would be benefited by the discovery of new fields. It is one of those objects of public utility which are especially worthy of the support of the British Association at this time and in this place.

II.-Stonesfield Slate. Report of the Comuittee, consisting of Mr. H. B. Woodward (Chairman), Mr. E. A. Walford (Secretary), Professor A. H. Green, Dr. H. Woodward, and Mr. J. Windoes, appointed to open further sections in the neighbourhood of Stonesfield in order to show the relationsbip of the Stonesfield Slate to the underlying and overlying strata. (Drawn up by Mr. Edwin A. WaLford, Secretary.)

TTHE basement beds of the Great Oolite in the Midlands and in the 1 south-west counties of England have been hitherto supposed to be well defined; for in all the records of the many writers on this geologic subdivision, to the Stonesfield Slate has been assigned the line of separation from the Fuller's Earth or Inferior Oolite, or, where the Stonesfield Slate is absent, as in the extreme west, to the Minchinhampton beds has been assigned the same position. Undue prominence has been given to so inconstant a set of beds as the Slate, as much from the ease with which fossils for its study have been collected as from the varied character of the fauna and flora found in it. From the days when the finding of the mammalian remains in the Slate called the attention of geologists prominently to it, every text-book of geology has found a place for it at the bottom of the Great Oolite limestones. Though, however, textbooks and papers have defined the lower boundary of the Great Oolite so clearly, the officers of the Geological Survey in their work in the neighbourhood of Stonesfield found the lines so difficult to define that it became necessary, where the Slate had disappeared, to adopt an intermediate colouring, a kind of no-man's-land. Since then an argillaceous stratum, "the Rift bed," has been recognised as the lowest of the Great Oolite beds in the Banbury and Hook Norton area.

The endeavour of the work, for which the British Association made a money grant in 1893, has been to ascertain the thickness and composition of the beds underlying the Slate, for hitherto no account of these beds has been obtainable, Prof. Ed. Hull's record ${ }^{1}$ of 70 feet being the only assumed thickness of the Great Oolite, and to this he adds 30 feet for the Inferior Oolite. Though their thickness seems to be over-estimated, no correction or account of a series of rocks so important has since then been made. Nearer Chipping Norton, however, Mr. J. Windoes, Mr. W. H. Hudleston,

1 Report Brit. Assoc. p. 82 (sections), 1860.

2 W. H. Hudleston, Proc. Geol. Assoc. vol. v. No. 7. 
and your Secretary ${ }^{1}$ have worked at some of the debatable beds above the Clypeus grit, one of the highest of the Cotswold divisions of the Inferior Oolite. To the bulk of these beds has been given the name of the "Chipping Norton Limestone" by Mr. Hudleston, and though the beds have not been reached in the section, they may be seen in the lane sections and near the spring on the banks of the Evenlode, south of Stonesfield. Your Secretary in 1892-93 sank a shaft near Ditchley, Oxon, to find out the true position of the Slate beds there; but of this an account will be published elsewhere.

The progress of the work, so far, at Stocky Bank, Stonesfield, has consisted in scarping the bank for 33 feet, and in continuing the section by carrying a shaft of 20 feet in depth through the lower bank. The purpose of the work has been so far successfully carried out by showing the existence of 30 feet of rock with some thin clay courses below the Slate. These limestones and clays (see accompanying section) are of Great Oolite type. To reach the Clypeus grit will need an extension of time and work.

Your Secretary has, by the discovery of numerous species of corals on the ploughed fields on the bank top, been able to define the Coral bed (Rift bed) ${ }^{2}$ so prominent a feature in the near section at Ashford bridge. Seventeen feet below the coral bed a course of Slate is met with, almost thinned out at that point, and only from 5 to 7 inches in thickness; the total thickness of it and the associated beds $(10,12,13$ of the section) being about 5 feet. The usual fossils, Trigonia impressa, etc., occur. In the lower limestones, 15 and 17, are greenish clay inclusions.

The great mass of buff limestone below the slate is almost unfossiliferous, and neither its mineralogical character nor its few fossils give sure evidence of its relationship to neighbouring beds.

Prominent in the lower half of the section is the breaking up of the calcareous series by small clay beds, and of these No. 23, with its dark compact clays, is in part made up of oyster-shell fragments. It contains numerous compressed shells, Perna quadrata, Nucula, etc., but washings of the beds yield hardly any microzoa. The limestone above the clay yields well-known Great Oolite shells, Mytilus Soucerbyanus, Rhychonella concinna, and Ostrea Sowerbyi. The shelly limestone below the clay is in part an Oyster lumachelle, and passes into a blue-hearted limestone with Perna quadrata, large Cyprine, Corbula, and Macrodon. Here, again, both petrological facies and fauna are dissimilar to any of our known Oxfordshire Oolitic rocks and, like each of the succeeding lower beds, should be classed as Great Oolite ; one of the latter, a hard, very oolitic freestone, has also as distinctive a character.

In conclusion, it should be stated that though, when Prof. Ed. Hull reported to your Association at its Oxford meeting, thirtyfour years ago (1860), the presence of seventy feet of Great Oolite limestone under the Stonesfield Slate, it seemed to be an over-

1 E. A. Walford, "On the Relation of the so-called Northampton Sand of North Oxon to Clypeus Grit," Q.J.G.S., vol. xxxix. p. 235.

2 E. A. Walford, Q.J.G.S. vol. xxxix. p. 230. 
estimate, yet the result of the present investigation has been to prove the presence of an important and overlooked section of the Great Oolite, and to entitle place for it in future accounts of that subdivision. That Prof. A. H. Green doubted the existence of so great a series of beds as those quoted by Prof. Hull is proved by the absence of any account of them in his excellent memoir "On the Geology of the Country round Banbury, Woodstock, Bicester, and Buckingham," published in 1864.

Mr. James Windoes, Mr. Wilfrid Hudleston, Mr. H. B. Woodward, and your Secretary have also worked in later years at the determination of the equivalent of these lower Bathonian beds in the neighbourhood of Chipping Norton.

To his Grace the Duke of Marlborough, to the Right Hon. Lord Dillon, to Mr. John Barrett of Stonesfield, and to Mr. S. Shilson of Charlbury, the thanks of your Committee are due for aid in this and other relative work.

The probable extension of a lower division of the Great Oolite, great enough to entitle it to a place as a sub-formation, below the limit reached by us makes a continuance of the work a necessity for the right understanding of the Lower Jurassic rocks of Great Britain.

Section at the S.W. end of Covert, Stocky Baxk, Stonesfield, Oxox, 1894.

1. Humus with limestone fragments containing Nerinaa, Cryptocania Prattii, E and H, Cryptocenia sp., Isastrea microphylla, Tomes, Isastrea limitata, Lamx., Iststrea near to limitata, Lamx., Thamnastrea Lyelli, E. and H., and Epismilia sp. "Ritt Bed" . . 09

2. Grey Marls with Ostrea, Placunopsis, and Rhynchonella concinna . $\quad 40$

3. Fawn-coloured Sands and Marls-Oyster bed . . . . . 20

4. Grey shelly compact Limestone, weathering cream-coloured . . . 60

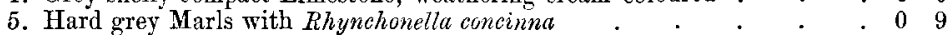

6. Shelly Limestone . . . . . . . . . . . . . 06

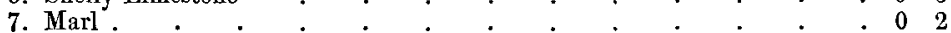

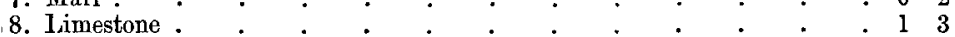

9. Marls with Oysters, etc. : - : - $\quad \cdot \quad \cdot \quad \cdot \quad$. $\quad$ - 26

10. Limestone, shelly Oolitic and cream-coloured "Roof" of Slate . $\quad 18$

11. Stonesfield Slate, "Top hard," compact, grey crystalline . 5 in. to 7 in.

12. Soft fissile Sandstone "Pendle". . . . . . 9 in. to 1 ft.

13. Limestone, coarsely fissile and Oolitic, with clay inclusions, concretions, black carbonaceous markings, and fragments of Rhynchonella and Trigonia impressa.

14. Marl, brown fissile and sandy

15. Shelly Limestone, laminated and banded with clay inclusions in the upper part; fawn coloured with Oysters . . . . . . . 23

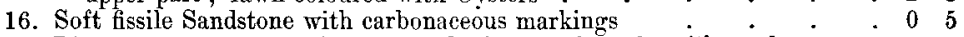

17. Limestone, compact, close-grained, fawn coloured, with carbonaceous markings and clay inclusions

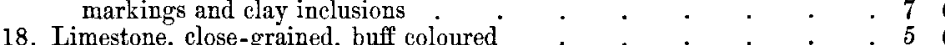

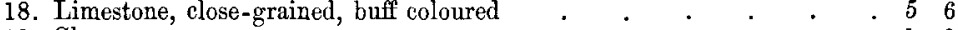

19. Clay. . . . . . . . . . . . 16

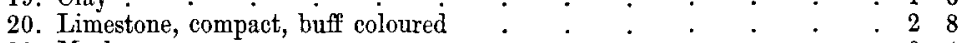

21. Marl . . . . . . . . . . . 04

22. Limestone, white, shelly, and crystalline, with Mytilus Sowerbyanus

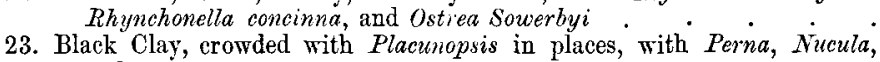
and Ostrea Limestone, made up mainly of $\dot{0}$ rster fragments, and

24. Shelly earthy Limestone, made up mainly of Oyster fragments, and
passing into a brown, blue-hearted Limestone crowded with shells, Perna quadrata, large Cyprina, Corbula, and ILacrodon . . 
25. Black Clay

Ft. in.

25. Black Clar. . . . . . . . . . 011

26. Hard Oolitic Freestone, blue-hearted, made up of whitish Oolites in blue

27. Rubble

or brown base . . . . . . . . . . . 2.20

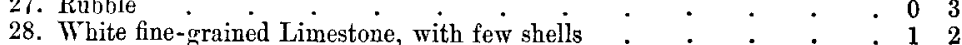

III.-On some Lacustrine Deposits of the Glactal Period in Middesex. By Henry Hrcks, M.D., F.R.S., F.G.S.

TN this paper the anthor refers to some deposits, consisting of 1 stratified gravels, sands, and clay, varying in thickness from a few feet to over 20 feet, which are spread out over the plateaux of Hendon, Finchley, and Whetstone. They are frequently covered over by the chalky Boulder-clay with northern erratics; but seldom themselves contain other materials than those which could have been derived from the Tertiary or Cretaceous series in the south-east of England. No marine fossils of contemporaneous age have been found in these deposits, but remains of land animals occur occasionally in and under them. The author has found that their geographical distribution is much greater than has usually been supposed, and he has been led to the conclusion that they must have been deposited in a lake, in the Glacial period, whose waters attained to a height of nearly 400 feet above present $O$. D. This lake, he believes, occupied a considerable area in the south-east of England, and spread for some distance south of the Thames, but was dammed up on the east and west. As the lake became gradually reduced in size, lakelets were formed in the Thames Valley, and most of the stratified deposits now found there, except those in the immediate proximity of the present Thames and its tributaries, date back to that period. Man, however, lived in the valley before any of these deposits were thrown down, hence it is that the flint implements and the mammalian remains usually occur under or in the lower parts of the deposits.

IV.-On the Terraced Hill Slopes of North Oxfordshire. By Edwin A. Walford, F.G.S.

7 HE green slopes of many of the minor vales of North Oxford1 shire are scored with parallel terraces or terraced banks, frequently of such regularity in depth of step and slope as to present to the mind any other origin for their formation than that of the every-day work of natural forces. They have been described as camps, entrenchments, and amphitheatres, and those of other districts Mr. Gomme has described, and has cited the many theories of their origin.

Mr. Walford first drew attention to the Oxfordshire and Warwickshire terraced fields in $1886,{ }^{1}$ and dealt at greater length with the subject in $1890 .^{2}$

1 E. A. Walford, "Edge Hill: the Battle and Battlefield," p. 24 (Banbury, 1886).

2 E. A. Walford, "On some Terraced Hill Slopes in the Midlands," Jouri. Northampton Nat. Hist. Soc., January, 1890.

DECADE IV.- - VOL. I.-No. $x$. 
He gives as causes of formation-

1. The downward creep of the surface and sub-surface soil.

2. The occurrence of the terraces upon one precise geologic line, the micaceous marls of the Middle Lias which come in below the Red Rock bed. The marls are porous and non-cohesive. On the slippery slopes the soil must oreep. The rain and rain-wash loosen the light soil below and about the roots of the herbage and urge its movement downward. Terraces from an incipient stage, like an ordinary grass ridge, to minor and major terraced banks of varying regularity of form can be traced. Below these marls are depths of compact blue clay (the zone of Ammonites margaritatus if in near contact with the marls). A little below the point where the marls and elays meet is the line of water outflow. Along the line there is constant removal of marl by chemical and mechanical solution. The effect is the loosening and sliding of the land downwards and outwards. This pressure is aided by the weight of the overlying mass of rock, sometimes twenty-five feet in thickness.

3. Free passage of water through the rock and marl is necessary, for the Upper Lias clays have on the Oxfordshire terraced hills either been wholly stripped from the hill top or pushed back by atmospheric denudation. Regularly terraced slopes are not found on clay-covered hills; the appearance of terraces is coincident with the wearing away of the clay "roof."

The amphitheatre form of terraced land is always a valley bead. The outflow of the stream-the valley-maker-marks ordinarily the base of the amphitheatre. More frequently the terraces of the valley head are small in slip and their eurvature is broken. Such an instance is Kenhill, near Shennington. An instance of greater regularity of curvature and greater depth of step is the Beargarden, Banbury.

From the Edge Hill escarpment a fork of the Horton vale runs alongside Adsum Plantation, and makes what is known as Adsum Hollow. The terraces sweep in regular curves along the high banks of the stream, and where it joins the main vale to the north of Horley the steps are so prominent as to give the name of Steps Meadow to the ground. Gredenton Hill, on the Burton Darrett range, is very regularly and beautifully terraced on three sides.

The author does not attempt description of the Chalk hills or the lynchets of Dorsetshire. The sandy marls of the Dorsetshire Inferior Oolite have a composition approaching that of the micaceous marls of the Midlands, and reasons like those brought forward will no doubt prove their similar mode of formation.

\section{正Vエ世W}

I.-Patamospongrologie; von Hermann Rauff. Erster Theil. $5^{\text {te }}$ und $6^{\text {te }}$ Lieferung. Mit 17 Tafeln und 27 Abbildungen im Text. Palæontographica. Band xl. Stuttgart, 1894, pp. 233-346. 7 HE previously issued (1-4) parts of Dr. Rauff's elaborate 1 Monograph on Fossil Sponges, which dealt with the general history, structure, and classification of the group, bave already been 